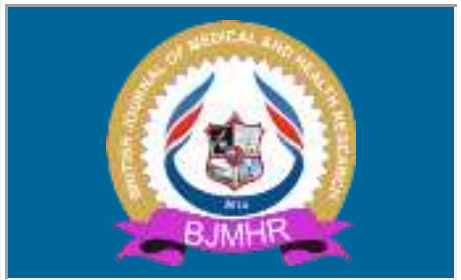

\title{
BJMHR
}

British Journal of Medical and Health Research

Journal home page: www.bjmhr.com

\section{Dental Caries Experience and Associated Risk Factors Among Pre-School Going Children In Bureti Sub-County, Kericho County, Kenya}

\author{
David Masinde ${ }^{1 *}$, Japheth Cheruiyot ${ }^{2}$ \\ 1.Maseno university, Kenya \\ 2.Medical Superintendent Kericho County Referral Hospital, Kenya
}

\section{ABSTRACT}

Globally, dental caries is one of the most prevalent dental health problem that affects children. Its prevalence in Bureti division is not known. The objectives were to determine dental caries experience, prevalence and risk factors associated with dental caries among pre-school going children of Bureti Sub-County, Kericho County. The Study population was all pre-school going children aged 3-6 years. The study utilized cross sectional descriptive design that involved quantitative techniques. The teeth of the children was examined at that point in time by a qualified dentist and also their caregivers/parents interviewed on oral health hygiene practices. The dmft scores was recorded. A proportionate stratified sampling technique was used to sample schools. Data was analysed using Stata version 12 and data presented in tables and graphs. Chi test was used to test for associations between outcome/dependent variables and independent variables. Regression analysis was done to establish significance of associations among dependent and independent variables. The mean age of children was 53.22 \pm 17.29 months, with boys being majority $(51.7 \%)$. The child age of starting brushing teeth was $3.5 \pm 0.94$ years. Majority $(63.88 \%)$ had dental caries. The mean dmft was $3.54 \pm 1.95$ with the greatest component being decayed teeth $(53.1 \%)$. Majority of the children $(62.26 \%)$ brush teeth with tooth paste and brush at least once weekly (61.73\%). The main risk factors for dental caries were mother's occupation $(\mathrm{OR}=3.18)$, Eating of sugary foods $(\mathrm{OR}=2.49)$, lack of brushing $(\mathrm{OR}=3.08)$, bottle feeding $(\mathrm{OR}=7.17)$, and poor social demographics. The prevalence of dental caries was high $(63.88 \%)$ and severe (mean $\mathrm{dmft}=3.54 \pm 1.9)$ which indicate high dental care treatment need. Consumption of sugary foods rich in cariogenic particles, poor social demographics of the caregivers, poor brushing of teeth, bottle feeding ( $p$-value $\leq 0.05$ ) are associated with high dental caries prevalence and dental caries experience.

Keywords: Dental Carries, Risk factors, Decayed teeth, Pre-school children

Please cite this article as: David M et al., Dental Caries Experience and Associated Risk Factors Among Pre-School Going Children In Bureti Sub-County, Kericho County, Kenya. British Journal of Medical and Health Research 2019. 


\section{INTRODUCTION}

Globally, dental caries one of the most prevalent dental health problem that affects children (Abdullah et al., 2008). Dental caries are defined as gradual irreversible decay of teeth resulting from a series of biochemical events occurring at a localized tooth site.

Dental caries is an infectious contagious disease caused by altered molecular interactions between the teeth's surface/subsurface and microbial biofilm. This lead to demineralization of the inorganic portion with subsequent destruction of the organic substance by producing cavities in the enamel and collateral damage in dentine and pulpar tissue (Kiwanuka et al., 2004; McDonald, Stookey and Avery, 2004). According to Kiwanuka et al., and Selwitz et al., the high consumption of dietary sugars, chronic exposure to fluoride and poor preventive measures such as lack of brushing, nonuse of tooth paste and use of bottle water especially at night contribute significantly to occurrence of dental caries (Kiwanuka et al., 2004; Selwitz et al., 2007). Tooth decay spread to the surrounding tissue causing inflammation and abscess formation, which can cause other health problems (Selwitz et al., 2007; WHO, 2007).

The World Health Organization (WHO) Oral Health Area profile program showed that $68 \%$ of 12 year old in one eighty four countries examined had less than three decayed/missing/filled teeth (dmft) (Petersen, 2004). The report demonstrated a gradual decrease in the incidence rates of dental caries among 12 year old children over a 30- year period. This was not the case in developing countries such as South Asia and Sub Saharan Africa where an increasing trend was observed (Petersen, 2004). The WHO/FDI has set a goal target for dental caries 50\% reduction among 5-6 years old children by the year 2000 and this has not been achieved (Liompart et al., 2010). A Brazilian found 55\% prevalence of dental caries among children less than less than 6 years (Ogido et al., 2004). In South Africa, the incidence rate of dental caries stood at 1.1\% in the year 2003 (South Africa Oral Health Survey, 2003). In the study area, dental caries is number four main cause of morbidity among under five year old children (DMOH, 2013) and accounts for up to $20 \%$ of morbidity cases. The factors contributing to these variations could be nutritional, socio-cultural, genetic, and/or environment of the victims.

\section{Problem Statement}

Dental caries in preschool going children are both an individual and community health problem. Dental caries can pose great physical pain and complications such dental alveolar abscess if not well treated. These dental alveolar complications can affect child early developmental milestones of children including poor dental structure and significant weight loss. This poses great burden not only to the patient, but also to his/her parents and society. It also leads to psychological trauma among affected children as it is associated with stigma and has been shown to affect academic performance. It also increases school absentism. It also 
reduces quality of life among affected children as it reduces ability of children to learn, sleep, play, eat and smile. Little attention and partly ignorance among parents/guardians on dental caries has lead to late diagnosis and treatment of dental caries and these has led to occurrence of dentalalveolar complications is associated with increased cost for treatment, hospitalization and overall increase in burden of health care. Dental caries is irreversible dental health condition and therefore prevention is most efficient way of managing it. Prevention is cheap but treatment of caries and accompanying complication is expensive. This study therefore seeks to investigate the caries experience and associated risk factors among pre-school going children in Bureti Division, Kericho County, Kenya.

\section{MATERIALS AND METHOD}

\section{Study Area:}

The study was conducted in selected pre-schools in Bureti Sub-County in Kericho County. Bureti Sub-County has approximately 22 public pre-schools and 27 private pre-schools. Bureti Sub-County lies between $0^{\circ} 50^{\prime}$ and $1^{\circ} 50^{\prime}$ South and Longitude $34^{\circ} 35^{\prime}$ east.

\section{Target Population:}

The target population comprised all the pre-school going children aged 3-6 years in Bureti SubCounty, Kericho County. The target population was all pre-school children meeting the study inclusion criteria in all the sampled schools. The pre-school going children include those in grade 1 , baby class, introductory, and kindergarten.

\section{Study Design:}

cross-sectional Study Design

\section{Determination of sample size:}

In order to be $95 \%$ sure that the proportion of children with dental caries among those attending kindergarten (preschool) is within plus or minus $5 \%$ of the population proportion of $50 \%$ a sample size was estimated using the following formula (Cochran, 1963).

$$
\mathrm{n}=\frac{\mathrm{Z}^{2} \mathrm{pq}}{\mathrm{d}^{2}}=\frac{1.96^{2} \times 0.5 \times 0.5}{0.05^{2}}=385
$$

Where;

$\mathrm{P}=$ is the population proportion of children with dental caries, $\mathrm{d}=1-\mathrm{p} ; \mathrm{d}=$ is the margin of error equal to the $5 \%$ used in this case, and $Z_{1-\alpha / 2}=$ is the $(1-\alpha / 2) \times 100 \%$ quartile of the standard normal distribution. Population less than 10,000. It then adjusted using population finite correction.

Adjusting for finite population size $\left(\frac{385}{1+385 / 9000}\right)=369$ participants as our number to study. 
A conservative value of $50 \%$ was used as the proportion of those with dental caries among the children attending pre-school was not known. The total number used in adjusting for finite population was obtained from survey conducted across the schools in the two zones. The sample size was allocated to the schools proportionately. Total sample size for girls and boys are equal but will be allocated proportionately in each school. See table 1

Table 1: Distribution of study participants

\begin{tabular}{lllllllll}
\hline School & Zone & Type & N & N_Boys & N_Girls & n_Boys & n_Girls & n \\
\hline Bargiro & Litein & Public & 44 & 24 & 20 & 10 & 8 & 18 \\
Kapkarin & Litein & Public & 101 & 57 & 44 & 23 & 18 & 41 \\
Ngeny & Litein & Public & 95 & 45 & 50 & 18 & 20 & 38 \\
Sinendet & Litein & Public & 32 & 18 & 14 & 7 & 6 & 13 \\
sambon AIC & Litein & Private & 38 & 22 & 16 & 9 & 7 & 15 \\
Isaiyana & Litein & Private & 57 & 26 & 31 & 10 & 13 & 23 \\
Sunshine & Litein & Private & 80 & 40 & 40 & 16 & 16 & 32 \\
Samoget & Litein & Private & 52 & 22 & 30 & 9 & 12 & 21 \\
Tiiritab Moita & Kapkatet & Public & 62 & 32 & 30 & 13 & 12 & 25 \\
Mabwaita B & Kapkatet & Public & 27 & 15 & 12 & 6 & 6 & 12 \\
Sebetet Pri & Kapkatet & Public & 75 & 33 & 42 & 13 & 17 & 30 \\
Kaptirbet & Kapkatet & Public & 35 & 18 & 17 & 7 & 7 & 14 \\
Nganaset & Kapkatet & Public & 105 & 48 & 57 & 19 & 23 & 42 \\
Koitabai Shephered & Kapkatet & Private & 36 & 23 & 13 & 9 & 5 & 15 \\
Perea Junior & Kapkatet & Private & 60 & 33 & 27 & 13 & 11 & 24 \\
Doves Kales Valley & Kapkatet & Private & 14 & 8 & 6 & 3 & 3 & 6 \\
Total & & & $\mathbf{9 1 3}$ & $\mathbf{4 6 4}$ & $\mathbf{4 4 9}$ & $\mathbf{1 8 5}$ & $\mathbf{1 8 3}$ & $\mathbf{3 6 9}$ \\
\hline
\end{tabular}

\section{Sampling procedures:}

Proportionate stratified random sampling was used to recruit the research participants.

\section{Data collection:}

Data was collected using self-administered structured questionnaire.

\section{Data analysis:}

Stata version 12 was used to manage data. Descriptive analyses was used to describe the sample such as socio-demographic characteristics and dental visits was analysis bivariate analysis was done to establish associations and relationships between independent variables (Sociodemographic such as age, gender, economic status of the family, parents education level and mouth and teeth hygiene practices such as source of drinking water and dental visits) and the outcome variable (dental caries experience and prevalence of dental caries). Thirdly, all the factors that was significant at bivariate level was entered into a multiple logistic regression model to identify significant predictors of dental experience. Significance was considered at $5 \% \alpha$-level.

\section{Ethical Consideration:}

Approval to carry out this study was sought from Maseno University's Ethics Review Committee (MUERC). 


\section{RESULTS AND DISCUSSION}

\section{Demographic characteristics}

A sample of 371 children and their parents/guardians was sampled from randomly selected 16 pre-schools with Bureti Sub-County. The mean age of the respondents was 53.22 ( $\mathrm{SD}=17.29)$ months. The mean age of children starting brushing was 3.55 ( $\mathrm{SD}=0.94)$ years. The demographic characteristics of the sample were summarized in table 2

Table 2: Demographic characteristics

\begin{tabular}{|c|c|c|c|}
\hline Characteristic & $\begin{array}{l}\text { Subgroup } \\
\text { (category) }\end{array}$ & Frequency (n) & Percent (\%) \\
\hline \multirow[t]{2}{*}{ Sex } & Male & 192 & 51.75 \\
\hline & Female & 179 & 48.25 \\
\hline \multirow[t]{2}{*}{ Religion } & Christian & 328 & 88.41 \\
\hline & Muslim & 43 & 11.59 \\
\hline \multirow[t]{3}{*}{ Class } & Baby class & 191 & 51.48 \\
\hline & pre unit & 38 & 10.24 \\
\hline & top class & 142 & 38.27 \\
\hline \multirow[t]{2}{*}{ School Category } & Private & 141 & 38.01 \\
\hline & Public & 230 & 61.99 \\
\hline \multirow[t]{3}{*}{ Fathers' Occupation } & Formally Employed & 142 & 38.27 \\
\hline & Self employed & 127 & 34.23 \\
\hline & unemployed & 102 & 27.49 \\
\hline \multirow[t]{3}{*}{ Mother's occupation } & Formally employed & 84 & 22.64 \\
\hline & Self employed & 115 & 31 \\
\hline & unemployed & 172 & 46.36 \\
\hline \multirow[t]{4}{*}{ Father's highest education level } & Primary & 0 & 0 \\
\hline & Secondary & 247 & 66.58 \\
\hline & University/college & 96 & 25.88 \\
\hline & None & 28 & 7.55 \\
\hline \multirow[t]{4}{*}{ Mothers' education level } & Primary & 89 & 23.99 \\
\hline & Secondary & 162 & 43.67 \\
\hline & University/college & 36 & 9.7 \\
\hline & none & 84 & 22.64 \\
\hline \multirow[t]{3}{*}{ Type of housing } & Stone wall & 138 & 37.2 \\
\hline & Timber & 130 & 35.04 \\
\hline & Mud wall & 103 & 27.76 \\
\hline
\end{tabular}

There was a slight majority of boys of $51.75 \%$. Majority of the respondent's profess Christian faith $(88.8 \%)$ and the $34.23 \%$ and $38.27 \%$ of the fathers were self-employed and formally employed, respectively. See table 2

\section{Prevalence of Dental Caries and Dental Caries Experience}

The overall prevalence of dental caries was $63.88 \%$ and among the boys alone, it was $41.77 \%$ (138) while 58.23\%(99) among girls. The mean dmft score among school going children was 3.54 with standard deviation of 1.95 . The mean dmft for girls was 4.68 while boys had mean of 3.17. The dmft range from $0-8$. 
When demographic characteristics was stratified by dental caries and caries experience, it was found that the prevalence of dental caries and mean dental caries experience was higher among preschool children and mostly in public schools and of the female gender compared to private schools counterparts and boys. Details are as shown in table 3. The mean dmft index was $3.54 \pm 1.9$ with the range of $0-8$.

Table 3: Household oral behavioral characteristics

\begin{tabular}{llcc}
\hline Characteristic & Category & n & $\mathbf{\%}$ \\
\hline Sugary foods & Yes & 235 & 63.34 \\
lack of brushing & Yes & 264 & 71.16 \\
Breast feeding & Yes & 122 & 32.88 \\
Bottle feeding & Yes & 149 & 40.16 \\
Brushing with tooth paste & Yes & 108 & 29.11 \\
limiting sugary food & Yes & 107 & 28.84 \\
Taking bottle of water at night instead of & & & \\
milk & Yes & 177 & 47.71 \\
Child frequency of brushing teeth & Daily & 87 & 23.45 \\
& weekly & 229 & 61.73 \\
& not applicable & 55 & 14.82 \\
Brushing teeth with tooth brush & Yes & 231 & 62.26 \\
Brushing teeth with sticks & Yes & 225 & 60.65 \\
Not brushing teeth & Yes & 14 & 3.77 \\
Child eats candy food & Yes & 273 & 73.58 \\
Parent talk with child over oral health & Yes & 149 & 40.16 \\
\hline
\end{tabular}

\section{Dental Caries and Related Risk Factors}

The risk factors for dental carries were investigated in this study. These include too much sugary food, use of bottle water and poor brushing methods.

When respondents was asked whether eating too much sugary food, or not brushing teeth, or bottle feeding at night, or brushing with tooth paste, or limiting the amount of sugary food or giving a child bottle of water at night instead of milk, are causing tooth decay in children, they gave varied reasons with majority reporting consumption of sugary food and not brushing being the cause of tooth decay in preschool children. Details, among others, are as shown in table 3. Majority ( $n=229,61.73 \%$ ) reported that their children brush teeth weekly, with 5(14.82\%) who are not able to brush teeth because they are too young and unable to do so. Majority, $225(60.65 \%)$, brush teeth with sticks and another $14(3.77 \%)$ do not brush at all yet they are able to do so. Most 273 (73.55\%) eat candy food with different frequencies. Upto 251 (67.6\%) of the children have never visited a dental specialist for oral health services. Approximately, $40.16 \%$ of children have never talked with their parents over oral health. 
Table 3: Cross Tabulation of Dental Caries and dmft with demographic characteristics

\begin{tabular}{llllllll}
\hline & \multicolumn{5}{c}{ Dental Caries } \\
Characteristic & & Yes & $\%$ & No & $\%$ & P-value \\
\hline Class & & & & & & \\
& Baby class & 100 & 42.19 & 91 & 67.91 & $<.0001$ \\
& Pre unit & 24 & 10.13 & 14 & 10.45 & \\
& Top class & 113 & 47.68 & 29 & 21.64 &
\end{tabular}

Sex

$\begin{array}{llllll}\text { Male } & 99 & 41.77 & 93 & 69.4 & <.0001 \\ \text { Female } & 138 & 58.23 & 41 & 30.6 & \\ & 62 & (36,72) & 43 & (37,68) & 0.2358 \\ & & & & & \\ \text { Christian } & 222 & 93.67 & 106 & 79.1 & <.0001 \\ \text { Muslim } & 15 & 6.33 & 28 & 20.9 & \end{array}$

School Category

$\begin{array}{llllll}\text { Private } & 89 & 37.55 & 52 & 38.81 & 0.8112 \\ \text { Public } & 148 & 62.45 & 82 & 61.19 & \end{array}$

dmft

Class

Sex

$\begin{array}{llll} & \text { N } & \text { Mean } & \text { Median } \\ \text { Baby class } & 163 & 3.00 & 3(2,4) \\ \text { Pre unit } & 38 & 3.76 & 3.5(3,4) \\ \text { Top class } & 137 & 4.98 & 5(4,6)\end{array}$

$\begin{array}{llll}\text { Male } & 178 & 3.17 & 3(2,4) \\ \text { Female } & 160 & 4.68 & 4(4,5)\end{array}$

Religion

$\begin{array}{llll}\text { Christian } & 309 & 4.10 & 4(3,5) \\ \text { Muslim } & 29 & 1.59 & 2(1,2)\end{array}$

School Category

$\begin{array}{llll}\text { Private } & 136 & 3.30 & 3(2,4) \\ \text { Public } & 202 & 4.28 & 4(3,5)\end{array}$

\section{Tooth Decay}

Class

N Mean Median

$\begin{array}{llll}\text { Baby class } & 65 & 1.00 & 1(1,1) \\ \text { Pre unit } & 19 & 2.00 & 2(2,2) \\ \text { Top class } & 113 & 3.52 & 3(2,4)\end{array}$

Sex

Religion

$\begin{array}{llll}\text { Male } & 99 & 2.04 & 1(1,3) \\ \text { Female } & 98 & 3.05 & 3(2,4)\end{array}$

School Category

$\begin{array}{llll}\text { Christian } & 183 & 2.66 & 2(1,4) \\ \text { Muslim } & 14 & 1.00 & 1(1,1)\end{array}$

$\begin{array}{llll}\text { Private } & 62 & 1.26 & 1(1,1) \\ \text { Public } & 135 & 3.13 & 3(2,4)\end{array}$

Missing Teeth 


\begin{tabular}{|c|c|c|c|c|}
\hline \multicolumn{5}{|l|}{ Class } \\
\hline & Baby class & 163 & 1.49 & $1(1,2)$ \\
\hline & pre unit & 38 & 1.50 & $1.5(1,2)$ \\
\hline & top class & 132 & 1.92 & $2(1,2)$ \\
\hline \multicolumn{5}{|l|}{ Sex } \\
\hline & Male & 173 & 1.51 & $1(1,2)$ \\
\hline & Feale & 160 & 1.83 & $2(1,2)$ \\
\hline \multicolumn{5}{|l|}{ Religion } \\
\hline & Christian & 304 & 1.72 & $2(1,2)$ \\
\hline & Muslim & 29 & 1.03 & $1(1,1)$ \\
\hline \multicolumn{5}{|l|}{ School Category } \\
\hline & Private & 131 & 1.45 & $1(1,2)$ \\
\hline & Public & 202 & 1.80 & $2(1,2)$ \\
\hline \multicolumn{5}{|l|}{ Filled Teeth } \\
\hline & & $\mathbf{N}$ & Mean & Median \\
\hline \multicolumn{5}{|l|}{ Class } \\
\hline & Baby class & 149 & 1.47 & $1(1,2)$ \\
\hline & pre unit & 24 & 2.00 & $2(2,2)$ \\
\hline & Top class & 53 & 1.19 & $1(1,1)$ \\
\hline \multicolumn{5}{|l|}{ Sex } \\
\hline & Female & 122 & 1.15 & $1(1,1)$ \\
\hline & Male & 104 & 1.83 & $2(2,2)$ \\
\hline \multicolumn{5}{|l|}{ Religion } \\
\hline & Christian & 211 & 1.49 & $1(1,2)$ \\
\hline & Muslim & 15 & 1.07 & $1(1,1)$ \\
\hline \multicolumn{5}{|l|}{ School Category } \\
\hline & Private & 133 & 1.59 & $2(1,2)$ \\
\hline & Public & 93 & 1.28 & $1(1,2)$ \\
\hline
\end{tabular}

When respondents was asked on the frequency of brushing their teeth, majority $(61.73 \%, n=229)$ reported that they brush their teeth once a week while $23.45 \%(n=87)$ reported that they brush at least once every day. Some respondents $(n=14,3.77 \%)$ reported that they do not brush their teeth

\section{Association between Dental Caries and Risk Factors}

Table 4 shows the risk factors of dental caries such as employment status, gender, age, school category (Public vs Private), Religion and Class. As shown in table, pre-school going children who were of the same gender, same age, same school category, belong to the same religion and are in the same class, a child whose mother is unemployed, is more than 3 times likely to get dental caries as compared to a child whose mother is formally employed (OR: $3.18,95 \% \mathrm{CI}$ : 1.49-6.79). There was no significant difference in risk of developing dental caries between a child whose mother is self-employed as compared to a child whose mother is formally employed (OR: 0.81, 95\% CI: 0.30-2.13).

A child who does not brush teeth is two time $(\mathrm{OR}=2.13)$ more likely to develop dental caries as compared to a child who brushes teeth. 
The expected number of dmft's for a child whose mother is unemployed is 0.62 times whose mother is formally employed. The expected number of dmft's for a child who is not bottle feeding is 1.31 times the expected number of a child who is bottle feeding. See table 5 .

Table 4: Adjusted logistic regression analysis

\begin{tabular}{|c|c|c|c|c|}
\hline Characteristic & & OR & Lower 95\% CI & Upper 95\% CI \\
\hline \multirow{2}{*}{$\begin{array}{l}\text { Mother's occupation } \\
\text { (ref=Formally employed) }\end{array}$} & Self employed & 0.81 & 0.30 & 2.13 \\
\hline & unemployed & 3.18 & 1.49 & 6.79 \\
\hline $\begin{array}{l}\text { Father's highest education } \\
\text { level(ref=Secondary) }\end{array}$ & University/college & 0.31 & 0.13 & 0.76 \\
\hline \multirow{3}{*}{$\begin{array}{l}\text { Mother's highest education } \\
\text { level(ref=Primary) }\end{array}$} & Secondary & 0.14 & 0.06 & 0.34 \\
\hline & none & 0.74 & 0.32 & 1.69 \\
\hline & University/college & 0.41 & 0.13 & 1.31 \\
\hline \multirow{2}{*}{$\begin{array}{l}\text { Type of house living } \\
\text { in(ref=Stone wall) }\end{array}$} & Timber & 16.66 & 7.88 & 35.23 \\
\hline & mud wall & 7.21 & 2.97 & 17.50 \\
\hline $\begin{array}{l}\text { Eating sugary } \\
\text { foods(ref=Yes) }\end{array}$ & yes & 2.09 & 1.11 & 3.93 \\
\hline lack of brushing(ref=Yes $)$ & yes & 2.13 & 1.08 & 4.19 \\
\hline Breast feeding(ref=Yes) & yes & 0.17 & 0.08 & 0.39 \\
\hline Bottle feeding(ref=Yes) & yes & 7.17 & 3.99 & 12.90 \\
\hline $\begin{array}{l}\text { Brushing with tooth } \\
\text { paste(ref=Yes) }\end{array}$ & yes & 0.02 & 0.00 & 0.11 \\
\hline $\begin{array}{l}\text { Taking bottle of water at } \\
\text { night instead of } \\
\text { milk(ref=Yes) }\end{array}$ & yes & 2.00 & 1.18 & 3.39 \\
\hline \multirow{2}{*}{$\begin{array}{l}\text { Child's frequency of brushing } \\
\text { teeth(ref=Daily) }\end{array}$} & not applicable & 0.37 & 0.12 & 1.13 \\
\hline & weekly & 0.16 & 0.06 & 0.42 \\
\hline $\begin{array}{l}\text { Brushing teeth with tooth } \\
\text { brush(ref=Yes) }\end{array}$ & No & 0.61 & 0.31 & 1.18 \\
\hline $\begin{array}{l}\text { Child eats candy } \\
\text { food(ref=Yes) }\end{array}$ & No & 0.18 & 0.10 & 0.35 \\
\hline \multirow{2}{*}{$\begin{array}{l}\text { Child Frequency of seeing } \\
\text { dental specialist(ref=Never } \\
\text { seen one) }\end{array}$} & once a year & 0.44 & 0.21 & 0.91 \\
\hline & once in 6 months & 0.31 & 0.10 & 0.96 \\
\hline Age started brushing teeth & & 0.58 & 0.37 & 0.92 \\
\hline
\end{tabular}

DISCUSSION, CONCLUSION AND RECOMMENDATIONS

\section{Prevalence of dental caries}

The prevalence of dental caries in the study population was high $(63.88 \%)$. This results are similar to NIH findings which showed that in United States, Dental caries is prevalent and upto five times more common than Asthma (NIH, 2000) and upto 80\% in Maharashtra, India (Shingare et al., 2012).

The present study finding contradicts a Nigerian study by Odegua and Alade (2017) that found much lower prevalence of dental caries in primary school pupils in Port Harcourt at $12.6 \%$ 
with lower prevalence of dental caries among the private school pupils (10.2\%) than in public school pupils (15\%). Another study in Nairobi carried out in 2001 found 63.5\% prevalence of dental caries among 3-5 years old pre-school going children (Ngatia et al., 2001). This is almost similar to the present study findings which found the prevalence of $63.88 \%$. This being urban area showed that there are other factors other than residence that could be significantly affecting the prevalence of dental caries and this include parental role in oral health education and access to oral health services.

The prevalence of dental caries among in developed countries are believed to be lower than those in developing countries. For instance, In Canada, the prevalence of dental caries was reported to be 52\% among 3- 5 years old preschool going children. The lower prevalence could be attributed to lower sugar consumption and possibly a higher oral health awareness among the caregivers. Optimal fluoride use could also be responsible for lower prevalence of dental caries in developed countries like Canada unlike in developing countries such as Kenya.

\section{Dental caries experience}

Dental caries experience was assessed using the dmft index which is universally employed to measure caries. It was observed that the present study findings are consistent with data reported by World Health Organization (WHO) that dental caries is a pandemic disease and wide spread (60\% to $90 \%)$ among school age children, including preschools'(Petersen et al., 2005). The mean dmft in the current study was $3.54 \pm 1.95$ with a range of $0-8$.

\section{Risk factors for dental caries and dental caries experience}

The level of oral health related knowledge among parents and caregivers is likely to influence the development of dental health habits in their children from the early age. This is due to the ability of children to model dental behaviors from their parents/caregivers. However, few studies have explored the relationship between parents/caregiver's level of oral health related knowledge and practices and preschool going children's prevalence of dental caries.

In the present study, oral health knowledge was relatively high. Majority of the respondents reported that eating of sugary food $(63.3 \%)$, lack of brushing $(71.1 \%)$, and not brushing teeth with tooth brush $(62.3 \%)$ was the main risk factors for occurrence of dental caries. Despite the relatively high level of knowledge on dental health, 273(73.6\%) children eats candy food with high carcinogenicity, with majority eating them more than twice a week (33\%) and only during the weekends (30\%). Quite a number of respondents (28.8\%) thought that limiting sugary food is the best way of reducing dental caries. Kiwanuka et al (2004) found that upto $98 \%$ of the children examined brushed teeth at least once daily and $99 \%$ used tooth paste unlike in the present study where $23.4 \%$ brush their teeth daily with majority $(61.73 \%)$ brushing at least once every week. However, there was no association between frequency of brushing teeth and 
incidences of dental caries, though more children brushing at least once weekly tend to have more incidences of dental caries compared to those brushing daily. A number of studies has demonstrated the oral care practices such as poor brushing of teeth, lack of use of tooth paste and poor knowledge of caregivers in occurrence of dental caries (Hallonsten et al., 1995; Mattila et al., 2000; Raadal et al., 2000).

The role of infant feeding practices on caries initiation was not known by the majority of the parents/caregivers. The practice of breast feeding and the 'bottle feeding at night' was reported to cause caries by $32.88 \%$ and $40.2 \%$ of the parents/caregivers, respectively. The Kenya Ministry of Health encourages exclusive breast-feeding especially in the first six months during ANC and MCH/FP clinics, though may not be accompanied by adequate oral health education. All these reflect a knowledge gap among parents/caregivers on the effect of infant feeding practices on dental caries prevention. Thus oral health education emphasizing the role of infant feeding practices on dental caries among 3-6 year old children is important and necessary among the parents and caregivers.

Lack of brushing teeth was identified as a risk factor with those not brushing having two times more risk for developing dental caries than those who brush (odd ration $=2.13$ ) and that those eating sugary food are twice likely to get dental caries (odd ratio=2.09). The expected number of $\mathrm{dmft}$ for a child who is not bottle-feeding is 1.31 times the expected number of a child who is bottle feeding. All these reflects the knowledge gaps and there is need for oral health education among parents/caregivers. There are consistent with many epidemiological studies relating to the dental health of toddlers and preschool children from the Nordic countries (Wendt et al., 1991, 1992, 1999; Grindefjord et al., 1993, 1995b; Hallonsten et al., 1995; Mattila et al., 1998, 2000; Raadal et al., 2000; Karjalainen et al., 2001; Stecksen-Blicks et al., 2004; Skeie et al., 2005b; Hugoson et al., 2008). All these have contributed to understanding the relationships and complexity of the caries disease among pre-school children.

\section{CONCLUSION}

The prevalence of dental caries among children aged 3-6 years was high (63.88\%) despite relatively high oral health knowledge of the causes and prevention of dental caries among parents/caregivers.. The caries experience as measured by the mean dmft-index was relatively high ( $3.54 \pm 1.9$ with the an interquartile range of $2-5$. The main risk factors associated with prevalence of dental caries and caries experience were unemployed status of the mother $(\mathrm{OR}=3.18)$, household type of housing ( $\mathrm{OR}=16.16$ for timber and $\mathrm{OR}=7.21$ for mud wall), eating sugary food $(\mathrm{OR}=2.09)$, lack of brushing $(\mathrm{OR}=2.13)$, bottle feeding $(\mathrm{OR}=7.17)$ and bottle of water at night instead of milk $(\mathrm{OR}=2.0)$.

\section{RECOMMENDATIONS}


1. Initiate health education programs integrated with $\mathrm{ANC}, \mathrm{MCH} / \mathrm{FP}$ and school health education programs.

2. Mobilize community oral health officers to perform regular dental check ups of preschool going children and educate their caregivers to enable prompt referral to the nearest dental health facility

3. More research should be conducted on factors influencing dental health seeking behaviors and dietary habits of preschool children in peri-urban and rural areas.

\section{REFERENCES}

1. Akpata ES. Oral Health in Nigeria. International Dental Journal 2004;54:361-366

2. Abolfotouh MA, Hassan KH, Khattab MS, Youssef RM, Sadek A, El-Sebaiei M. Dental Caries: Experience in Relation to Wasting and Stunted Growth Among Schoolboys in Abha, Saudi Arabia. Ann Saudi Med 2000;20(5-6):360-3.

3. Al-Haddad, AS. Bin Ghouth, HS. Hassan. Distribution of Dental Caries among Primary School Children in Al-Mukalla Area, Yemen. Journal of Dentistry, Tehran University of Medical Sciences, Tehran, Iran (2006; Vol: 3, No.4)

4. Adekoya - Sofowora CA, WO Nasir, AO Oginni, M Taiwo. Caries, Prevalence, Dental, Attendance, Behaviour, Suburban, Children, Survey, Nigeria. African Health Sciences 2006; 6(3): 145-150

5. Alaluusua S, Malmivirta R. Early plaque accumulation - A sign for caries risk in young children. Community Dent Oral Epidemiol 1994;22(10):273-6.

6. Al Malik MI, Holt RD, Bedi R (2003). Prevalence and patterns of caries, rampant caries and oral health in two-five year old children in Saudi ARABIA. Journal Dent Child (chic). 70:3. 235-42

7. Beirut D, Helderman WHP. Oral Health in Syria. International Dental Journal 2004; $54: 383-388$

8. Benard-Bonnin AC, Pelletier H, Turgeon JP, Allard-Dansereau C, Petit N, Chabot G, Masson P (1993). Cariogenic feeding habits and fluoride supplementation during infancy and early childhood. Can J Public Health. 84:2.90-2

9. Begzati A, Meqa K, Siegenthaler D, et al: Dental health evaluation of children in Kosovo. Europ J of Dent 2011, 5:32-39.

10. Burt BA, Satishchandra P. The relationship between low birthweight and subsequent development of caries: A systematic review. J Dent Ed 2001;65(10):1017-23.

11. Cataldo WL, Oppenheim FG. Physical and chemical aspects of saliva as indicators of risk for dental caries in humans. J Dent Ed 2001;65(10):1054-62.

12. Cleaton-Jones P, Fatti P. Dental caries trend in Africa. Community Dent Oral 
Epidemiol. 1999 Oct;27(5):316-20.

13. Currie C, Hurrelmann K, et al: Health and health behaviors among young people. Copenhagen; WHO regional office for Europe; 2000 WHO policy series. Health policy for children and adolescents, (1). International report. Accessed on 30th April 2014.

14. Carino KM, Shinada K, Kiwaguchi Y (2003). ECC in northern Phillipines. Comm Dent Oral Epi. 31:2.81-9

15. Department of Health. Report: National Children's Oral Health Survey. South Africa;2003:1-18

16. District Medical officer of Health, Bureti district, 2014

17. Eunice Ogido, Cassia Dezan, Wanda Garbeilini,Fernanda Salomao, and Maria Morita. Prevalence of dental carries among children in Brazilian city. J Appl Oral Sci 2004; 12(1): $34-8$

18. Eronat N. and Koparal E (1997). Dental caries prevalence, dietary habits, tooth brushing and Mothers' education in 500 urban Turkish children. J Marmara Univ Dent Fac. 2:4. 599-604

19. Kassim BA, Noor MA, Chindia ML. Oral Health status among Kenyans in a rural arid setting: dental caries experience and knowledge on its causes. East Afr Med J. 2006;83(2):100-5.

20. Kiwanuka SN, Astrm AN,and Trovikta (2004). Dental caries experience and its relationship to social and behavioural factors among 3- years old children in Uganda. International Joirnal Paediatr Dent. 14: 336-346

21. Mahejabeen R, Sudha P, Kulkarni SS, Anegundi R: Dental caries prevalence among preschool children of Hubli: Dharwad city. J Indian Soc Pedod Prev Dent 2006, 24:1922.

22. Murray JJ, Naylor MN. Fluorides and dental caries. In: Murray JJ, ed. Prevention of Oral Disease. Oxford University Press, Oxford; 1996:32-67.

23. Mbawalla, H.S., J.R. Masalu, and A.N. Åstrøm, Socio-demographic and behavioral correlates of oral hygiene status and oral health related quality of life, the LimpopoArusha School project (LASH): A cross-sectional study. BMC Pediatrics, 2010. 10: 87.

24. Narendar Davani, Nighar Nisar, Nazeer Khan, Shahbano Syed and Navara Tanweer. BMC Oral Health 2012, 12:59 http://www.biomedcentral.com/1472-6831/12/59

25. Ng'ang'a PM, Valderhaug J. Dental caries in primary school children in Nairobi, Kenya. Acta Odontol Scand. 1992;50:269-72.

26. Ngatia EM, Imungi JK, Muita JW, Nganga PM (2001). Dietary patterns of and dental caries in nursery school children in Nairobi, Kenya. Eaast Afr Med J. 78:12. 673-7 
27. Nunn ME, Dietrich T, Singh HK, Henshaw MM, Kres- sin NR. Prevalence of early childhood caries among very young urban Boston children compared with US Children. J Public Health Dent 2009;69(3):156-62.

28. Petersen PE. Challenges to Improvement of Oral Health in the $21^{\text {st }}$ century-The approach of the WHO Global Oral Health Programme. International Dental Journal 2004;54:329-343

29. Petersen PE. Strengthening the prevention of HIV/AIDS related Oral Disease: A Global Approach. Community Dentistry and Oral Epidemiology 2004; 32:399-401

30. Petersen PE, Bourgeois D, Ogawa H, Estupinan-Day S, Ndiaye C. The Global burden of oral disease and risks to oral health. Bull World Health Organ. 2005 Sep;83(9):6619.

31. Petterson GH, Brathall D. The caries decline: A review of reviews. Eur J Oral Sci. 1996; 104:436-443.

32. Peressini S, Leake JL, Mayhall JT, Maar M, Trudeau R (2004). Prevalence of early childhood caries among First Nations' children, District of Manitoulin, Ontario. Int J Paediatr Dent. 14:2. 110-10

33. Polk, D.E., R.J. Weyant, and M.C. Manz, Socio-economic factors in adolescents' oral health: are they mediated by oral hygiene behaviors or preventive interventions? Community Dent Oral Epidemiol, 2010. 38: p. 1-9.

34. Reisine S, Douglass JM. Psychosocial and behavioral issues in early childhood caries. Community Dent Oral Epidemiol 1998;26(1 Suppl):45-8.

35. Reisine ST, Psoter W. Socioeconomic status and selected behavioral determinants and risk factor for dental caries. J Dent Ed 2001;65(10):1009-16.

36. Simratvir M, Moghe GA, Thomas AM, Singh N, Chopra S: Evaluation of caries experience in 3-6-year-old children, and dental attitudes amongstthe care-givers in the Ludhiana city. J Indian Pedod Prev Dent 2009, 27:164-169.

37. Singh S, Myburgh NG, Lallo R. Policy Analysis of Oral Health Promotion in South Africa, Global Health Promotion 2010;17(1):16-24

38. Liompart G, Marin GH, Silberman M, Merlo I, Zurriaga O: Oral health in 6- year old schoolchildren from berisso, Argentina: falling far short of WHO goals. Med Oral Patol Oral Cir Bucal 2010, 15:101-105.

39. Tickle M, Craven RJ, Milsom KM, Kay EJ. The relative effects of residential and school environments on the dental caries experience of 5- and 12-year-old children in the north west of England. Health Education Journal 2001;60(2):120-6.

40. Thibodeau EA, O’Sullivan DM, Tinanoff N. Mutans streptococci and caries prevalence 
in preschool children. Community Dent Oral Epidemiol 1993;21(5):288-91.

41. Litt MD, Reisine S, Tinanoff N. Multidimensional causal model of dental caries development in low-income preschool children. Public Health Reports 1995;110(4):607-17.

42. Ly KA, Milgrom P, Rothen M. Xylitol, sweeteners, and dental caries. Pediatr Dent 2006;28(2):154-63.

43. Sabbah, W., et al., The role of health related behaviors in the socioeconomic disparities in oral health. Soc Sci Med, 2008: p. 1 - 6.

44. Sanders, A., A. Spencer, and G. Slade, Evaluating the role of dental behavior in oral health inequalities. Community Dent Oral Epidemiol, 2006. 34(1): p. 71 - 79.

45. Vadiakas G. Case definition, aetiology and risk assessment of early childhood caries (ECC): A revisited review. European Arch Paed Dent 2008;9(9):114-25.

46. Weatherell J, Deutsch D, Robinson C, Hallsworth AS. Assimilation of fluoride by enamel throughout the life of the tooth. Caries Res 1977;11(2):85-115.

47. World Health Organization: Application of the international classification of disease to dentistry and stomatology Geneva, WHO; 1996.

48. Eigbobo JO, Alade G. Dental caries experience in primary school pupils in Port Harcourt, Nigeria. Sahel Med J 2017;20:179-86

49. Akpata ES. Oral health in Nigeria. Int Dent J 2004;54:361-6.

50. Masumo R, Bardsen A, Mashoto K, Šstrøm AN. Prevalence and socio-behavioral influence of early childhood caries, ECC, and feeding habits among 6-36 months old children in Uganda and Tanzania. BMC Oral Health 2012;12:24.

51. Okeigbemen, SA, UC Nnawuihe, and C Osemwegie. Dental caries experience and oral health behavior among 7-15 years old children attending military and paramilitary schools in Benin City. Savannah Journal of Medical Research and Practice (2015). Vol $4 ; 1$

52. Sufia S, Chaudhry S, Izhar F, Syed A, Mirza BA, Khan AA. Dental caries experience in preschool children: is it related to a child's place of residence and family income? Oral Health Prev Dent. 2011;9(4):375-9.

53. Shingare P, Jogani V, Seveker S, Patil S, Jha M. Dental caries prevalence among 3 to 14 year old school children, Uran, Raigad district, Maharashtra. J Contemp Dent Pract 2012;2:11-4.

54. Ambarkova V, Ivanova V. Dental caries experience among primary school children in the Eastern region of the republic of Macedonia. Oral Health Dent Manag 2014;13:17. 
55. U.S. Department of Health and Human Services. Oral Health in America: A Report of the Surgeon General. Rockville: U.S. Department of Health and Human Services, National Institute of Dental and Craniofacial Research, National Institutes of Health; 2000

56. Petersen PE, Bourgeois D, Ogawa H, Estupinan-Day S, Ndiaye C. The global burden of oral diseases and risks to oral health. Bull World Health Organ 2005;83:661-9.

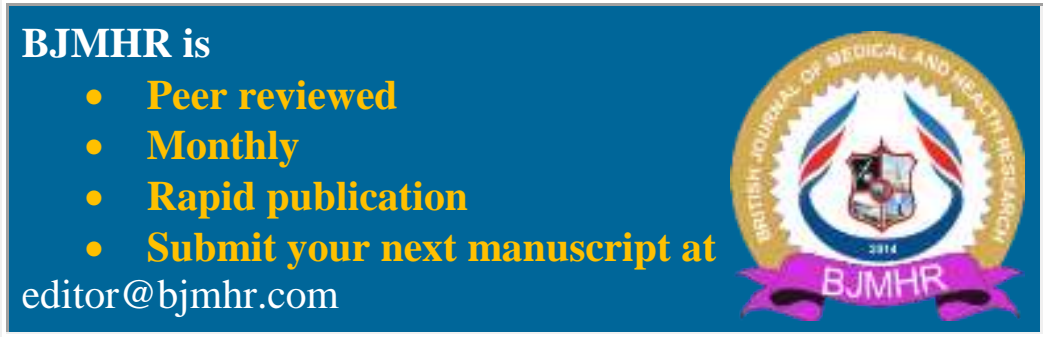

